Research

\title{
Study of the impact of perilipin polymorphisms in a French population
}

\author{
Aline Meirhaeghe*1, Séverine Thomas ${ }^{1}$, Frédéric Ancot ${ }^{1}$, Dominique Cottel ${ }^{1}$, \\ Dominique Arveiler $^{2}$, Jean Ferrières ${ }^{3}$ and Philippe Amouyel ${ }^{1}$
}

Address: ${ }^{1}$ INSERM, U744, Lille; Institut Pasteur de Lille, Lille; Université de Lille 2, Lille, France, ${ }^{2}$ Department of Epidemiology and Public Health, Faculty of Medicine, Strasbourg, France and ${ }^{3}$ INSERM, U558, Faculté de Médecine, Toulouse, France

Email: Aline Meirhaeghe* - Aline.Meirhaeghe-Hurez@pasteur-lille.fr; Séverine Thomas - thomasseverine@wanadoo.fr; Frédéric Ancot - frederic.ancot@ibl.fr; Dominique Cottel - Dominique.Cottel@pasteur-lille.fr; Dominique Arveiler - monica@medecine.ustrasbg.fr; Jean Ferrières - ferriere@mail.cict.fr; Philippe Amouyel - Philippe.Amouyel@pasteur-lille.fr

* Corresponding author

Published: 12 July 2006

Journal of Negative Results in BioMedicine 2006, 5:10 doi:10.1 I86/I477-575I-5-10

This article is available from: http://www.jnrbm.com/content/5/I/I0

(C) 2006 Meirhaeghe et al; licensee BioMed Central Ltd.

This is an Open Access article distributed under the terms of the Creative Commons Attribution License (http://creativecommons.org/licenses/by/2.0), which permits unrestricted use, distribution, and reproduction in any medium, provided the original work is properly cited.

\begin{abstract}
Background: Perilipins are proteins localized at the surface of the lipid droplet in adipocytes, steroid-producing cells and ruptured atherosclerotic plaques playing a role in the regulation of triglyceride deposition and mobilization. We investigated whether perilipin gene polymorphisms were associated with obesity, type 2 diabetes, and their related variables (anthropometric variables, plasma leptin, lipids, glucose and insulin concentrations) in a cross-sectional random sample of I I 20 French men and women aged 35 to 65 years old, including 227 obese (BMI $\geq 30 \mathrm{~kg} / \mathrm{m}^{2}$ ) and 275 type 2 diabetes subjects.
\end{abstract}

Results: Among 7 perilipin polymorphisms tested, only 2 ( $r$ 4557862I and rs894I60) of them were frequent enough to be fully investigated and we genotyped the sample using the PCR-RFLP method. No significant associations could be found between any of these polymorphisms and the studied phenotypes.

Conclusion: The rs457862I and rs894160 polymorphisms of the perilipin gene are not major genetic determinants of obesity and type 2 diabetes-related phenotypes in a random sample of French men and women.

\section{Background}

Perilipins are phosphorylated proteins in adipocytes localized at the surface of the lipid droplet in adipocytes, steroid-producing cells and ruptured atherosclerotic plaques [1-4]. These proteins are essential in the regulation of triglyceride deposition and mobilization [5-7]. When protein kinase $\mathrm{A}$ is activated, perilipin A becomes phosphorylated and translocates away from the lipid droplet, which allows hormone-sensitive lipase to hydrolyse the adipocyte triglyceride core $[8,9]$. Therefore, peril- ipin A increases cellular triglyceride storage by decreasing the rate of triglyceride hydrolysis. Mice knockout for the perilipin gene are lean, have increased basal lipolysis and are resistant to diet-induced obesity $[10,11]$. However, these mice also develop glucose intolerance and insulin resistance more readily, probably due to the elevated levels of non-esterified fatty acids.

Several studies determined the level of perilipin expression according to obesity status. Two studies found obese 
subjects displayed lower levels of perilipin than lean individuals $[7,12]$ whereas another study showed perilipin mRNA and protein were elevated in obese subjects [13]. Qi et al. previously showed that polymorphisms in the perilipin locus were associated with obesity-related phenotypes in American and Spanish White women [14,15]. Moreover, they showed that a particular haplotype was associated with increased obesity risk in Malays and Indians, but not in Chinese [16]. In this study, we examined the genetic variability of the perilipin gene and possible associations with obesity, type 2 diabetes and related phenotypes in a French random sample of population.

\section{Results}

Table 1 describes the genotyping conditions and frequencies of the 7 tested PLIN SNPs (issued from the NCBI dbSNP database). DNA from 90 individuals issued from the population study was used to estimate the SNP frequencies. The rs8179072 (A386V), rs8179070 (R274W), rs3743373 (E293K) SNPs were not detected at all. Only 1 heterozygote for both the rs6496589 (Pro194Ala) and rs8179071 (Ser348Leu) SNPs could be found (rare allele frequency $=0.6 \%$ ). Therefore we did not pursue the genotyping of these SNPs. The rare allele frequencies of the rs4578621 (5'UTR -1234 C>G) and rs894160 (intron 6) SNPs were 7.6 and $30 \%$ respectively. Therefore, we genotyped these two SNPs in the whole population study ( $\mathrm{n}=$ 1120). There were 958 (85.5\%) GG, 153 (13.7\%) GA, 9 (0.8\%) AA and 556 (49.6\%) GG, 470 (42.0\%) GA and 94 (8.4\%) AA for the rs4578621 and rs894160 SNPs respectively. These frequencies were not different from the expected frequencies under Hardy-Weinberg equilibrium.

We compared the genotype distribution of the two SNPs according to BMI categories (normal weight: $\mathrm{BMI}<25 \mathrm{~kg} /$ $\mathrm{m}^{2}$, overweight : $25 \leq \mathrm{BMI}<30 \mathrm{~kg} / \mathrm{m}^{2}$ and obese : $\mathrm{BMI} \geq 30$ $\mathrm{kg} / \mathrm{m}^{2}$ ) and diabetes status in men and women separately (table 2). No significant differences in the SNPs frequency could be detected between BMI or diabetes categories.

Table 3 and 4 show the impact of the PLIN rs 4578621 and rs894160 SNPs respectively on anthropometric and biological variables in men and women separately. The means of anthropometric variables (weight, BMI, waist and hip circumferences, or waist-to-hip ratio), plasma lipid (plasma cholesterol, HDL-cholesterol, LDL-cholesterol, triglycerides) or insulin concentrations were not statistically different between genotype groups neither in men nor in women. Men carrying the rare $A A$ genotype of the rs894160 SNP had lower fasting plasma glucose levels than GG subjects $(5.27 \pm 0.64$ vs. $5.56 \pm 0.90 \mathrm{mmol} / \mathrm{L}$ or $1.65 \pm 0.12$ vs. $1.71 \pm 0.15 \log$-transformed values for $A A$ vs $G G$ men respectively, $\mathrm{p}=0.04$ when adjusted for covariates).

Between the two SNPs, the linkage disequilibrium D' was 0.87 ( $p<0.0001$ ), the G allele of the rs4578621 SNPS being associated with the A allele of the rs894160 SNP, and the $\mathrm{r}^{2}$ was 0.15 . Therefore, three haplotypes covered $99 \%$ of the possible haplotypes (haplotype frequencies, CG: 0.70, CA: 0.22, GA: 0.07). No significant association could be found between haplotypes and the phenotypes studied (data not shown).

\section{Discussion}

In the present study, we assessed the impact of the genetic variability of the PLIN gene on obesity, type 2 diabetes and related phenotypes in a sample of men and women issued from a French random sample of population ( $\mathrm{n}=$ 1120). The genotyping of two common SNPs (rs4578621

Table I: Description of PLIN SNPs, primers, PCR conditions and restriction enzymes.

\begin{tabular}{|c|c|c|c|c|c|c|c|c|}
\hline SNP & Primers & PCR (bp) & $\mathrm{MgCl}_{2}(\mathrm{mM})$ & Ann. temp. & RE & $\begin{array}{l}\text { Size (bp) for the wt } \\
\text { allele }\end{array}$ & $\begin{array}{l}\text { Size (bp) for the } \\
\text { mut allele }\end{array}$ & $\operatorname{MAF}(\%)$ \\
\hline rs 4578621 & $\begin{array}{l}\text { F : CAAGCTGGGTGCACTGGC } \\
\text { R: GAGAAATAGAGGAATTAACC }\end{array}$ & 185 & 0.9 & 58 & Mnll & $33+152$ & $33+62+90$ & 7.6 \\
\hline rs6496589 & $\begin{array}{l}\mathrm{F}: \text { CTGCCAACACTCG AGCTG } \\
\mathrm{R}: \text { ACCTGACTCTTCCTTGTCT }\end{array}$ & 110 & 1 & 60 & Pstl & $72+28$ & no cut & 0.6 \\
\hline \multirow[t]{2}{*}{ rs894160 } & $\begin{array}{l}\mathrm{FI}: \text { GCTGAGACTGAGTCACATGC } \\
\mathrm{RI}: \text { GCTGAGACTGAGTCACATGC }\end{array}$ & 403 & 0.5 & 60 & - & - & - & - \\
\hline & $\begin{array}{l}\text { F2 : CTGTTTGTGGGGCTCCCTCG } \\
\text { R2 : CCTCCCAGATCTTTTAAGAG }\end{array}$ & 126 (nested) & 0.5 & 52 & Xhol & 126 & $20+106$ & 30.0 \\
\hline rs8179070 & $\begin{array}{l}\mathrm{F}: \text { CAGCTATCTGCTGCCATC } \\
\mathrm{R}: \text { CTCACTGAACTTGTTCTCC }\end{array}$ & 219 & 0.5 & 58 & Mspl & $75+144$ & 219 & ND \\
\hline rs3743373 & $\begin{array}{l}\mathrm{F}: \text { CAGCTATCTGCTGCCATC } \\
\mathrm{R}: \text { CTCACTGAACTTGTTCTCC }\end{array}$ & 219 & 0.5 & 58 & BseRI & $96+49+45+21+5+3$ & $96+94+21+5+3$ & ND \\
\hline rs817907। & $\begin{array}{l}\mathrm{F}: \text { GTAGCAGCCCTGCCAGGCC } \\
\mathrm{R}: \text { CCGGCACGTAATGCACCAC }\end{array}$ & 248 & 0.5 & 69 & BstXI & $66+182$ & $66+129+53$ & 0.6 \\
\hline rs8179072 & $\begin{array}{l}\text { F : GTAGCAGCCCTGCCAGGCC } \\
\text { R: CCGGCACGTAATGCACCAC }\end{array}$ & 248 & 0.5 & 69 & Hpy / 88III & 248 & $80+168$ & ND \\
\hline
\end{tabular}

F : forward, R : reverse, wt allele : wild-type (common) allele, mut allele : mutant (rare) allele, Ann. : annealing, temp. : temperature, RE: restriction enzyme, MAF: minor allele frequency.

The SNP allele frequencies were determined in 90 individuals. 
Table 2: Genotype distribution of the PLIN rs457862 I and rs894I60 SNP according to BMI categories and diabetes status

\begin{tabular}{|c|c|c|c|c|c|c|c|}
\hline & \multicolumn{3}{|c|}{ rs457862I } & \multicolumn{4}{|c|}{ rs894160 } \\
\hline & CC & $\mathbf{C G}+\mathbf{G G}$ & $p$ & GG & GA & AA & $p$ \\
\hline & \multicolumn{3}{|c|}{ Men } & \multicolumn{4}{|c|}{ Men } \\
\hline $\mathrm{BMI}<25 \mathrm{~kg} / \mathrm{m}^{2}(228)$ & $194(85.1)$ & $34(14.9)$ & & $109(47.8)$ & $97(42.5)$ & $22(9.7)$ & \\
\hline $25 \leq \mathrm{BMI}<30 \mathrm{~kg} / \mathrm{m}^{2}(238)$ & $204(85.7)$ & $34(14.3)$ & ns & II $3(47.5)$ & $103(43.3)$ & $22(9.2)$ & ns \\
\hline $\mathrm{BMI} \geq 30 \mathrm{~kg} / \mathrm{m}^{2}(104)$ & $91(87.5)$ & $13(12.5)$ & & $58(55.8)$ & $36(34.6)$ & $10(9.6)$ & \\
\hline Non-diabetic (397) & $337(84.9)$ & $60(15.1)$ & & $186(46.9)$ & $168(42.3)$ & $43(10.8)$ & \\
\hline \multirow[t]{2}{*}{ Diabetic $(151 \mathrm{M} / 160 \mathrm{~W})$} & $127(84.1)$ & $24(15.9)$ & ns & $82(51.3)$ & $62(38.7)$ & $16(10.0)$ & ns \\
\hline & \multicolumn{3}{|c|}{ Women } & \multicolumn{4}{|c|}{ Women } \\
\hline $\mathrm{BMI}<25 \mathrm{~kg} / \mathrm{m}^{2}(249)$ & $216(86.8)$ & $33(13.2)$ & & $129(51.8)$ & $97(39.0)$ & $23(9.2)$ & \\
\hline $25 \leq \mathrm{BMI}<30 \mathrm{~kg} / \mathrm{m}^{2}(\mathrm{I} 72)$ & $145(84.3)$ & $27(15.7)$ & ns & $87(50.6)$ & $79(45.9)$ & $6(3.5)$ & ns \\
\hline $\mathrm{BMI} \geq 30 \mathrm{~kg} / \mathrm{m}^{2}(\mathrm{I} 23)$ & $103(83.7)$ & $20(16.3)$ & & $58(47.2)$ & $54(43.9)$ & II (8.9) & \\
\hline Non-diabetic (439) & $382(87.0)$ & $57(13.0)$ & & $220(50.1)$ & $188(42.8)$ & $31(7.1)$ & \\
\hline Diabetic (108 M/II5 W) & $91(84.3)$ & 17 (15.7) & ns & $66(57.4)$ & $39(33.9)$ & $10(8.7)$ & ns \\
\hline
\end{tabular}

Data are $\mathrm{n}(\%)$. Among the II 20 individuals genotyped, data on BMI or diabetes status were missing for few subjects. M: men, W: women.

and rs894160, frequency $=7.6$ and $30 \%$ respectively) were performed. No significant associations could be detected between these SNPs and the anthropometric variables, plasma leptin, lipids, glucose and insulin concentrations, even when using haplotype analyses.

The only significant association we found in our study was that men carrying the rare AA genotype of the rs894160 SNP (also called $11482 \mathrm{G}>\mathrm{A}$ ) had significant lower fasting plasma glucose levels than GG subjects but this difference was statistically borderline ( $\mathrm{p}=0.04)$ and clinically marginal (around 5\% lower) and therefore this association is not clinically of great consequence and probably obtained by hazard. Moreover, this polymorphism was not associated with type 2 diabetes neither in men, nor in women in our study. Although the $11482 \mathrm{G}>\mathrm{A}$ SNP seems to have a functional impact on the perilipin protein activity as Mottagui-Tabar et al. reported that the A allele was associated with enhanced basal and noradrenaline-induced lipolysis in human subcutaneous fat cells [7], it does not seem to have a major impact in human French populations.

Other studies have previously described associations between PLIN SNPs and obesity-related phenotypes, especially the rs894160 (11482 G>A) SNP. Qi L et al. showed that a PLIN specific haplotype was associated with an increased risk of obesity in Malays, Indians and Whites (odds ratio around 1.7) [14-16]. In Whites, the PLIN $11482 \mathrm{G}>\mathrm{A}$ was associated with obesity risk in women but not in men. We were not able to reproduce this association in our French study. Although our study bears on a large number of subjects (573 men, 547 women), its statistical power may still be insufficient to detect small associations. This hypothesis is supported by an a posteriori calculation which indicates that according to the observed allele distribution, the sample size has sufficient statistical power $(1-\beta \geq 80 \%)$ to detect an odds ratio above 2.4 and 2.1 for obesity and 2.1 and 1.8 for type 2 diabetes for the rs4578621 and rs894160 SNPs respectively. Therefore, only major associations could be detected. Moreover, we can not exclude that other PLIN SNPs that we did not explore, taken individually or in haplotype combinations, might be associated with obesity phenotypes.

\section{Conclusion}

In conclusion, the PLIN rs4578621 and rs894160 polymorphisms do not seem to be major genetic determinants of obesity and type 2 diabetes risk in French men and women. Other larger studies and/or other PLIN SNPs may need to be studied to conclude definitely about the impact of the PLIN gene variability on metabolic diseases.

\section{Methods}

\section{Study subjects}

Participants were recruited within the framework of the WHO-MONICA population survey conducted from 1995 to 1997 in the Urban Community of Lille in the North of France. The sample included subjects aged 35-65 years, randomly selected from the electoral rolls to obtain 200 participants for each gender and 10-year age group $[17,18]$. A total number of 601 men and 594 women was recruited. To our knowledge, no individuals were related. 
Table 3: Impact of the PLIN rs457862 I SNP on clinical variables in men and women separately

\begin{tabular}{|c|c|c|c|c|}
\hline & \multicolumn{2}{|c|}{ Men } & \multicolumn{2}{|c|}{ Women } \\
\hline & $\begin{array}{l}\text { CC } \\
487\end{array}$ & $\begin{array}{c}\mathbf{C G}+\mathbf{G G} \\
81\end{array}$ & $\begin{array}{l}\text { CC } \\
462\end{array}$ & $\begin{array}{c}\mathbf{C G}+\mathbf{G G} \\
80\end{array}$ \\
\hline Weight, kg & $79.9 \pm 13.6$ & $79.6 \pm 12.9$ & $68.1 \pm 14.5$ & $70.8 \pm 15.2$ \\
\hline $\mathrm{BMI}, \mathrm{kg} / \mathrm{m}^{2}$ & $26.7 \pm 4.2$ & $26.0 \pm 3.6$ & $26.4 \pm 5.4$ & $27.3 \pm 5.9$ \\
\hline Waist, $\mathrm{cm}$ & $96.2 \pm 11.0$ & $95.2 \pm 9.8$ & $85.3 \pm 13.8$ & $87.9 \pm 15.0$ \\
\hline Hip circ., cm & $101.5 \pm 7.4$ & $101.6 \pm 6.8$ & $103.5 \pm 11.6$ & $105.0 \pm 12.7$ \\
\hline WHR & $0.95 \pm 0.07$ & $0.94 \pm 0.06$ & $0.82 \pm 0.08$ & $0.83 \pm 0.08$ \\
\hline Leptin, ng/mL $\dagger$ & $9.48 \pm 7.75$ & $18.16 \pm 6.59$ & $24.08 \pm 13.90$ & $24.17 \pm 14.98$ \\
\hline Cholesterol, mmol/L & $5.88 \pm 1.06$ & $5.92 \pm 0.94$ & $5.92 \pm 1.11$ & $6.08 \pm 1.13$ \\
\hline HDL-chol., mmol/L & $1.34 \pm 0.42$ & $1.31 \pm 0.36$ & $1.67 \pm 0.49$ & $1.66 \pm 0.49$ \\
\hline LDL-chol., mmol/L & $3.86 \pm 1.02$ & $3.89 \pm 0.86$ & $3.71 \pm 1.04$ & $3.90 \pm 1.08$ \\
\hline Triglycerides, $\mathrm{mmol} / \mathrm{L} \dagger$ & $1.64 \pm 1.38$ & $1.69 \pm 1.52$ & $1.19 \pm 0.80$ & $1.25 \pm 1.37$ \\
\hline Glucose, $\mathrm{mmol} / \mathrm{L} \dagger$ & $5.66 \pm 1.37$ & $5.52 \pm 1.45$ & $5.33 \pm 1.28$ & $5.56 \pm 1.41$ \\
\hline Insulin, $\mu \mathrm{U} / \mathrm{mL} \dagger$ & $12.37 \pm 9.35$ & $11.95 \pm 10.01$ & $11.63 \pm 6.00$ & $12.06 \pm 5.84$ \\
\hline
\end{tabular}

† These variables were log-transformed to obtain normal distributions. Circ. : circumference. WHR : waist-to-hip ratio. Chol. : cholesterol. Among the II 20 individuals genotyped, data on several variables were missing for few subjects.

The Ethical Committee of Lille University Hospital (CHRU de Lille) approved the protocol.

After signing an informed consent, participants were administered a standard questionnaire and physical measurements were made by a trained nurse. The level of physical activity was defined as: walking or riding $15 \mathrm{~min}$ or more per day, and/or lifting or carrying heavy objects at work daily, and/or doing sport or physical exercise more than 2 hours a week. Current cigarette smokers were defined as subjects reporting at least one cigarette per day.
Total alcohol intake was expressed as the sum of $\mathrm{ml}$ alcohol per week from wine, beer, cider and spirits.

The anthropometric measurements included body weight, waist and hip circumferences. BMI was calculated according to the Quetelet equation. Blood pressure was measured on the right arm, with the subject in a sitting position and after a minimum 5-min rest, using a standard mercury sphygmomanometer. The mean value of two consecutive blood pressure readings was taken into

Table 4: Impact of the PLIN rs894I60 SNP on clinical variables in men and women separately

\begin{tabular}{|c|c|c|c|c|c|c|}
\hline & \multicolumn{3}{|c|}{ Men } & \multicolumn{3}{|c|}{ Women } \\
\hline & GG & GA & AA & GG & GA & AA \\
\hline & 281 & 235 & 54 & 272 & 231 & 39 \\
\hline Weight, kg & $80.2 \pm \mid 4.1$ & $79.2 \pm 12.8$ & $81.1 \pm 13.2$ & $67.5 \pm \mid 4.1$ & $69.9 \pm 14.6$ & $67.9 \pm 16.8$ \\
\hline $\mathrm{BMI}, \mathrm{kg} / \mathrm{m}^{2}$ & $26.9 \pm 4.3$ & $26.3 \pm 4.0$ & $26.3 \pm 3.7$ & $26.2 \pm 5.3$ & $27.0 \pm 5.4$ & $26.7 \pm 7.1$ \\
\hline Waist, cm & $96.5 \pm 11.4$ & $95.5 \pm 10.2$ & $96.3 \pm 10.3$ & $84.7 \pm 13.4$ & $87.0 \pm 14.1$ & $84.3 \pm 16.9$ \\
\hline Hip circ., cm & $101.7 \pm 7.5$ & $101.4 \pm 7.3$ & $101.4 \pm 7.1$ & $102.9 \pm 11.1$ & $104.6 \pm 11.8$ & $103.7 \pm 15.5$ \\
\hline WHR & $0.95 \pm 0.07$ & $0.94 \pm 0.07$ & $0.95 \pm 0.07$ & $0.82 \pm 0.08$ & $0.83 \pm 0.08$ & $0.81 \pm 0.07$ \\
\hline Leptin, ng/mL ${ }^{\dagger}$ & $9.60 \pm 7.90$ & $9.18 \pm 7.55$ & $8.24 \pm 6.19$ & $23.12 \pm 13.72$ & $25.26 \pm 14.52$ & $23.79 \pm 13.28$ \\
\hline Cholesterol, mmol/L & $5.93 \pm 1.10$ & $5.83 \pm 1.00$ & $5.86 \pm 0.90$ & $5.90 \pm 1.18$ & $6.01 \pm 1.05$ & $5.93 \pm 1.11$ \\
\hline HDL-chol., mmol/L & $1.33 \pm 0.4 \mathrm{I}$ & $\mathrm{I} .37 \pm 0.4 \mathrm{I}$ & $1.24 \pm 0.37$ & $1.65 \pm 0.5 \mathrm{I}$ & $1.68 \pm 0.47$ & $1.69 \pm 0.43$ \\
\hline LDL-chol., mmol/L & $3.90 \pm 1.05$ & $3.79 \pm 0.96$ & $3.99 \pm 0.85$ & $3.69 \pm 1.10$ & $3.80 \pm 0.99$ & $3.68 \pm 1.05$ \\
\hline Triglycerides, mmol/L† & $1.71 \pm 1.42$ & $|.57 \pm| .3 \mid$ & $1.68 \pm 1.66$ & $1.21 \pm 0.87$ & $1.19 \pm 0.97$ & $1.16 \pm 0.77$ \\
\hline Glucose, $\mathrm{mmol} / \mathrm{L} \dagger$ & $5.56 \pm 0.90$ & $5.49 \pm 0.85$ & $5.27 \pm 0.64^{*}$ & $5.40 \pm 1.41$ & $5.42 \pm 1.71$ & $5.64 \pm 1.55$ \\
\hline Insulin, $\mu \mathrm{U} / \mathrm{mL}^{\dagger}$ & $12.52 \pm 9.48$ & $11.93 \pm 8.16$ & $12.83 \pm 13.62$ & $1 \mathrm{I} .47 \pm 5.86$ & $11.83 \pm 5.87$ & $12.43 \pm 7.32$ \\
\hline
\end{tabular}

*crude $\mathrm{p}<0.03$ or $\mathrm{p}<0.04$ when adjusted for age, BMI, smoking and alcohol consumptions with a recessive model (adjusted means $5.5 \mathrm{I} \pm 0.05$ for GG vs $5.52 \pm 0.05$ for GA vs $5.28 \pm 0.11$ for $A A$ subjects). $\dagger$ These variables were log-transformed to obtain normal distributions. Circ. : circumference. WHR : waist-to-hip ratio. Chol. : cholesterol. Among the II 20 individuals genotyped, data on several variables were missing for few subjects. 
account. From this sample, 232 subjects were obese (BMI $\geq 30 \mathrm{~kg} / \mathrm{m}^{2}$ ).

Individuals with type 2 diabetes $(\mathrm{n}=275)$ were identified on the basis of a medical diagnosis and/or fasting glycae$\mathrm{mia} \geq 7 \mathrm{mmol} / \mathrm{L}(1.26 \mathrm{~g} / \mathrm{L})$ and/or on the existence of a specific treatment or diet [19] in the Lille sample and in two other representative French samples (Strasbourg, Toulouse) participating to the risk factor surveys of the WHO-MONICA project. Control subjects for type 2 diabetes had fasting glycaemia $<6.1 \mathrm{mmol} / \mathrm{L}(1.10 \mathrm{~g} / \mathrm{L})$ and had no specific treatment or diet for type 2 diabetes.

\section{Laboratory methods}

A blood sample of $20 \mathrm{~mL}$ was drawn on disodium EDTA after the subjects had fasted for at least 10 hours. Lipid and lipoprotein levels were measured in a central laboratory Purpan Hospital Biochemical Laboratory (Toulouse). The quality of biological measures was assessed within the framework of the MONICA Project. Glucose was measured by a standard glucose hexokinase method (DuPont Dimension, Brussels, Belgium). Plasma insulin was measured by radio-immunoassay (Medgenix Diagnostics, Brussels, Belgium). Plasma total cholesterol and triglyceride levels were measured by enzymatic methods (DuPont Dimension Brussels, Belgium). High density lipoprotein (HDL) cholesterol was measured after sodium phosphotungstate/magnesium chloride precipitation (Boehringer Mannheim, Mannheim, Germany). Low density lipoprotein (LDL) cholesterol was calculated with the Friedewald equation. Plasma leptin levels were measured by radioimmunoassay (Human leptin RIA kit, Wak-Chemie, Medical GmbH, Germany).

\section{DNA isolation and genotyping}

Genomic DNA was extracted from white blood cells isolated from $20 \mathrm{ml}$ of whole blood using a commercially available DNA isolation kit (DNA extraction kit, Stratagene, La Jolla, CA, USA). Genomic DNA was available for 1155 subjects. The PCR and genotyping conditions for the SNPs (single nucleotide polymorphisms) are described in table 1. A total of 1120 subjects were genotyped for the PLIN rs4578621 and rs894160 SNPs.

\section{Statistical analyses}

Chi-square analysis or Fisher exact tests were used to compare genotype and allele distributions between groups. Comparison of differences among genotype groups were tested using a general linear model (proc GLM). Adjustment variables were : age, alcohol, smoking, and physical activity for the anthropometric variables and age, BMI, alcohol, and smoking for the biological variables. A dominant model was tested for the rs 4578621 SNP due to the low number of homozygotes for the rare allele. A dominant and a recessive model were tested for the rs894160
SNP. Analyses were performed with the SAS statistical software release 8 (SAS Institute Inc, Cary, NC). Haplotype analyses were based on the maximum likelihood model described in and linked to the SEM algorithm $[20,21]$ and performed using the software developed by the INSERM U525, Paris, France (available at http://gene canvas.ecgene.net/downloads.php). Statistical significance was defined at the $5 \%$ level. Power calculation was done with the Epi Info 6.04 software available on http:// www.cdc.gov/epiinfo/. The statistical power (1- $\beta$ ) was set above $80 \%$.

\section{Competing interests}

The author(s) declare that they have no competing interests.

\section{Authors' contributions}

FA, ST genotyped the population samples. AM analyzed the data and wrote the paper. DC, DA, JF and PA enrolled the participants and contributed to writing the paper.

\section{Acknowledgements}

These population surveys were supported by unrestricted grants from the Conseil Régional du Nord-Pas de Calais, ONIVINS, Parke- Davies Laboratory, the Mutuelle Générale de l'Education Nationale (MGEN), Groupe Fournier, the Réseau National de Santé Publique, the Direction Générale de la Santé, the Institut National de la Santé Et de la Recherche Médicale (INSERM), the Institut Pasteur de Lille, the Unité d'Evaluation du Centre Hospitalier et Universitaire de Lille, the Centre d'Examen de Santé de Strasbourg, the CPAM de Sélestat and the Fédération Régionale de Cardiologie d'Alsace. The Fondation de France is also acknowledged for its financial support.

\section{References}

I. Greenberg AS, Egan JJ, Wek SA, Moos MC Jr, Londos C, Kimmel AR: Isolation of CDNAs for perilipins $A$ and $B$ : sequence and expression of lipid droplet-associated proteins of adipocytes. Proc Natl Acad Sci USA 1993, 90: 12035 -I 2039.

2. Servetnick DA, Brasaemle DL, Gruia-Gray J, Kimmel AR, Wolff J, Londos C: Perilipins are associated with cholesteryl ester droplets in steroidogenic adrenal cortical and Leydig cells. J Biol Chem 1995, 270:16970-16973.

3. Blanchette-Mackie EJ, Dwyer NK, Barber T, Coxey RA, Takeda T, Rondinone CM, et al.: Perilipin is located on the surface layer of intracellular lipid droplets in adipocytes. J Lipid Res 1995, 36:1211-1226.

4. Faber BC, Cleutjens KB, Niessen RL, Aarts PL, Boon W, Greenberg $A S$, et al.: Identification of genes potentially involved in rupture of human atherosclerotic plaques. Circ Res 200I, 89:547-554.

5. Souza SC, de Vargas LM, Yamamoto MT, Lien P, Franciosa MD, Moss LG, et al.: Overexpression of perilipin A and B blocks the ability of tumor necrosis factor alpha to increase lipolysis in 3T3LI adipocytes. J Biol Chem 1998, 273:24665-24669.

6. Brasaemle DL, Rubin B, Harten IA, Gruia-Gray J, Kimmel AR, Londos $C$ : Perilipin A increases triacylglycerol storage by decreasing the rate of triacylglycerol hydrolysis. J Biol Chem 2000, 275:38486-38493.

7. Mottagui-Tabar S, Ryden M, Lofgren P, Faulds G, Hoffstedt J, Brookes A], et al.: Evidence for an important role of perilipin in the regulation of human adipocyte lipolysis. Diabetologia 2003, 46:789-797.

8. Sztalryd C, Xu G, Dorward H, Tansey JT, Contreras JA, Kimmel AR, et al.: Perilipin $A$ is essential for the translocation of hormone- 
sensitive lipase during lipolytic activation. J Cell Biol 2003, 16 I:1093-1103.

9. Fricke K, Heitland A, Maronde E: Cooperative activation of lipolysis by protein kinase $A$ and protein kinase $C$ pathways in 3T3-LI adipocytes. Endocrinology 2004, I 45:4940-4947.

10. Martinez-Botas J, Anderson JB, Tessier D, Lapillonne A, Chang BH, Quast MJ, et al.: Absence of perilipin results in leanness and reverses obesity in Lepr(db/db) mice. Nat Genet 2000, 26:474-479.

II. Tansey JT, Sztalryd C, Gruia-Gray J, Roush DL, Zee JV, Gavrilova O, et al:: Perilipin ablation results in a lean mouse with aberrant adipocyte lipolysis, enhanced leptin production, and resistance to diet-induced obesity. Proc Natl Acad Sci USA 200I, 98:6494-6499.

12. Wang Y, Sullivan S, Trujillo M, Lee MJ, Schneider SH, Brolin RE, et al:: Perilipin expression in human adipose tissues: effects of severe obesity, gender, and depot. Obes Res 2003, I I:930-936.

13. Kern PA, Di Gregorio G, Lu T, Rassouli N, Ranganathan G: Perilipin expression in human adipose tissue is elevated with obesity. J Clin Endocrinol Metab 2004, 89: I 352-I 358.

14. Qi L, Shen H, Larson I, Schaefer EJ, Greenberg AS, Tregouet DA, et al.: Gender-specific association of a perilipin gene haplotype with obesity risk in a white population. Obes Res 2004, I 2:1758-1765

15. Qi L, Corella D, Sorli JV, Portoles O, Shen H, Coltell O, et al:: Genetic variation at the perilipin (PLIN) locus is associated with obesity-related phenotypes in White women. Clin Genet 2004, 66:299-310.

16. Qi L, Tai ES, Tan CE, Shen H, Chew SK, Greenberg AS, et al.: Intragenic linkage disequilibrium structure of the human perilipin gene (PLIN) and haplotype association with increased obesity risk in a multiethnic Asian population. J Mol Med 2005, 83:448-456

17. Ecological analysis of the association between mortality and major risk factors of cardiovascular disease. The World Health Organization MONICA Project. Int J Epidemiol 1994, 23:505-516.

18. Aaronson DS, Horvath CM: A road map for those who know JAK-STAT. Science 2002, 296:1653-1655.

19. Report of the Expert Committee on the Diagnosis and Classification of Diabetes Mellitus. Diabetes Care 1997, 20: $1183-1197$

20. Tregouet DA, Barbaux S, Escolano S, Tahri N, Golmard JL, Tiret L, et al: Specific haplotypes of the P-selectin gene are associated with myocardial infarction. Hum Mol Genet 2002, II:20I5-2023.

21. Tregouet DA, Escolano S, Tiret L, Mallet A, Golmard JL: A new algorithm for haplotype-based association analysis: the Stochastic-EM algorithm. Ann Hum Genet 2004, 68: 165-177.
Publish with Bio Med Central and every scientist can read your work free of charge

"BioMed Central will be the most significant development for disseminating the results of biomedical research in our lifetime. "

Sir Paul Nurse, Cancer Research UK

Your research papers will be:

- available free of charge to the entire biomedical community

- peer reviewed and published immediately upon acceptance

- cited in PubMed and archived on PubMed Central

- yours - you keep the copyright
BioMedcentral 